УДК 553.411:412 (571.6)

\title{
О ГЕОЛОГИЧЕСКОМ И ИЗОТОПНОМ ВОЗРАСТЕ ЗОЛОТОРУДНЫХ МЕСТОРОЖДЕНИЙ НА ПРИМЕРЕ ЗОЛОТО-СЕРЕБРЯНОГО МЕСТОРОЖДЕНИЯ КУБАКА (Северо-Восток России)*
}

\author{
Степанов В. $А$. \\ ФГБУН Научно-исследовательский геотехнологический центр, г. Петропавловск-Камчатский \\ E-mail: vitstepanov@yandex.ru
}

\begin{abstract}
Приведены сведения о геологическом и изотопном возрасте золото-серебряного месторождения Кубака Омолонского срединного массива Северо-Востока России. Установлено, что геологический возраст месторождения Кубака находится в вилке между позднедевонским возрастом вмещающих золото-серебряное оруденение вулканитов кедонской серии и раннекаменноугольным возрастом перекрывающих вулканиты и оруденение терригенных пород корбинской свиты. Показан пострудный характер даек омолонского комплекса, которые существенно не влияют на распределение золотой минерализации в рудных телах. По данным изотопного датирования выделяются следующие этапы формирования Кубакинского месторождения: накопление туфов кубакинской свиты (369 млн лет) - внедрение субвулканических интрузий (344 и 337 млн лет), образование околорудных метасоматитов ( $335 \pm 5$ млн лет), формирование золото-серебряного оруденения входит в диапазон 330 и 334-324 млн лет, внедрение пострудных даек $-179 \pm 8-176 \pm 10$ млн лет.
\end{abstract}

Ключевые слова: золото-серебряное месторождение, возраст оруденения, изотопное датирование, пострудные дайки, вулканиты, метасоматиты.

DOI: $10.34078 / 1814-0998-2021-1-3-12$

\section{ВВЕДЕНИЕ}

Определение возраста эндогенных рудных месторождений, в отличие от месторождений осадочных, нередко вызывает некоторые трудности. Особенно это касается руд не магматической, а гидротермальной группы, в том числе и золоторудных месторождений, генетическая связь которых с конкретными датированными магматическими комплексами часто далеко не очевидна. Определение возраста золоторудных месторождений не только носит чисто познавательный интерес, но и в целом определяет направление поисковых работ на золото. В качестве примера для сравнительного анализа определений возраста золотого оруденения геологическими и изотопными методами выбрано месторождение Кубака - крупнейшее вулканогенное месторождения золота СевероВостока, расположенное в пределах Омолонской золотоносной провинции (Горячев и др., 2017) России.

\footnotetext{
(C) Степанов В. А., 2021

*В порядке обсуждения (ред.).
}

\section{МЕТОДЫ ОПРЕДЕЛЕНИЯ ВОЗРАСТА РУДНЫХ МЕСТОРОЖДЕНИЙ}

Существуют два метода определения возраста рудных месторождений, в том числе и золоторудных, - геологический и изотопный. Оба имеют свои положительные и отрицательные моменты. Геологический метод основан на определении нижней и верхней границы возраста. Нижней границей является возраст наиболее молодых вмещающих оруденение пород, верхней возраст наиболее древних перекрывающих оруденение толщ или пострудных интрузий и даек. Геологический возраст месторождения оказывается в вилке между нижней и верхней границами. Но этот разрыв часто бывает очень велик. Например, в Приамурской провинции золотое оруденение часто размещается в гнейсах и кристаллосланцах протерозойского или архейского возраста, в то время как оруденение имеет позднемезозойский возраст. Перекрывающие толщи, кроме современных аллювиальных и делювиальных осадков, в Приамурье обычно отсутствуют. С установлением возраста сопровождающих оруденение син- и внутрирудных интрузий и даек мезозойского возраста также возникают определенные трудности. Не- 
сколько лучше обстоит дело с определением геологического возраста месторождений вулканогенной золото-серебряной формации. Генетическая связь месторождений этого типа с вмещающими вулканическими комплексами достаточно очевидна. Важную роль играет обнаружение рудокласт, т. е. обломков руды в перекрывающих оруденение толщах. Их наличие четко указывает на верхнюю возрастную границу месторождения.

Определение возраста золоторудных месторождений изотопными методами также сталкивается с определенными трудностями. Для определения изотопного возраста наиболее точным и распространенным U-Pb методом необходим радиоактивный минерал, чаще всего это циркон. Метод хорош для определения изотопного возраста магматических пород. Но в рудах большинства золоторудных месторождений циркона нет. Исключение представляют лишь комплексные золото-медно-молибденпорфировые месторождения. Распространенные K-Ar и Ar-Ar методы основаны на радиогенном накоплении аргона в калиевых минералах - полевых шпатах и слюдах, $\mathrm{a} \mathrm{Rb}-\mathrm{Sr}$ на радиоактивном распаде изотопа рубидий87 и превращении его в изотоп стронция-87. Методы экспрессные и неплохо зарекомендовали себя. Но ими устанавливается изотопный возраст не рудных, а лишь сопровождающих оруденение минералов.

К сожалению, изотопный возраст самородного золота установить невозможно, поскольку в природе существует лишь один стабильный изотоп этого элемента $-{ }^{197} \mathrm{Au}$. Не поможет и изотопия серебра, наиболее распространенной примеси самородного золота. В природе отмечаются два его стабильных изотопа $-{ }^{107} \mathrm{Ag}$ и ${ }^{109} \mathrm{Ag}$. Heкоторый научный интерес может представлять часто отмечаемая в золоте примесь ртути. Она встречается в значительных количествах (проценты) в золоте месторождений от архейского (месторождение Витватерсранд) до кайнозойского (золото-серебряные месторождения Камчатки) возраста (Степанов, Моисеенко, 1993). В отличие от золота и серебра природная ртуть имеет семь стабильных и ряд радиоактивных изотопов (Bainbridge, Nier, 1950). При распаде радиоактивных изотопов ртути возникают изотопы платины, золота и таллия. Не исключено, что эти реакции когда-нибудь можно будет использовать для определения изотопного возраста ртутьсодержащего золота.

\section{ГЕОЛОГИЧЕСКИЙ ВОЗРАСТ}

В пределах Омолонского срединного массива расположены золото-серебряные месторождения Кубака, Биркачан и Ольча палеозойского возрас- та, а на периферии массива, уже в зоне ОхотскоЧукотского вулканогенного пояса (ОЧВП) - месторождения Эвенское и Дукат мезозойского возраста (рис. 1). Золото-серебряное месторождение Кубака находится в Ауланджинском рудном узле Южно-Омолонского рудного района Омолонской золотоносной провинции (Степанов, Шишакова, 1994; Наталенко и др., 2002; Горячев и др., 2017; Акинин и др., 2020). Узлу отвечает Авландинская положительная палеовулканическая структура центрального типа площадью около 30 км² (Степанов, Шишакова, 1994). Палеовулкан хорошо отпрепарирован в рельефе, структура его дешифрируется на аэрофотоматериалах. В нем выделяются жерловая, околожерловая и периферическая части, разделенные концентрическими разломами. Жерло вулканоструктуры сложено

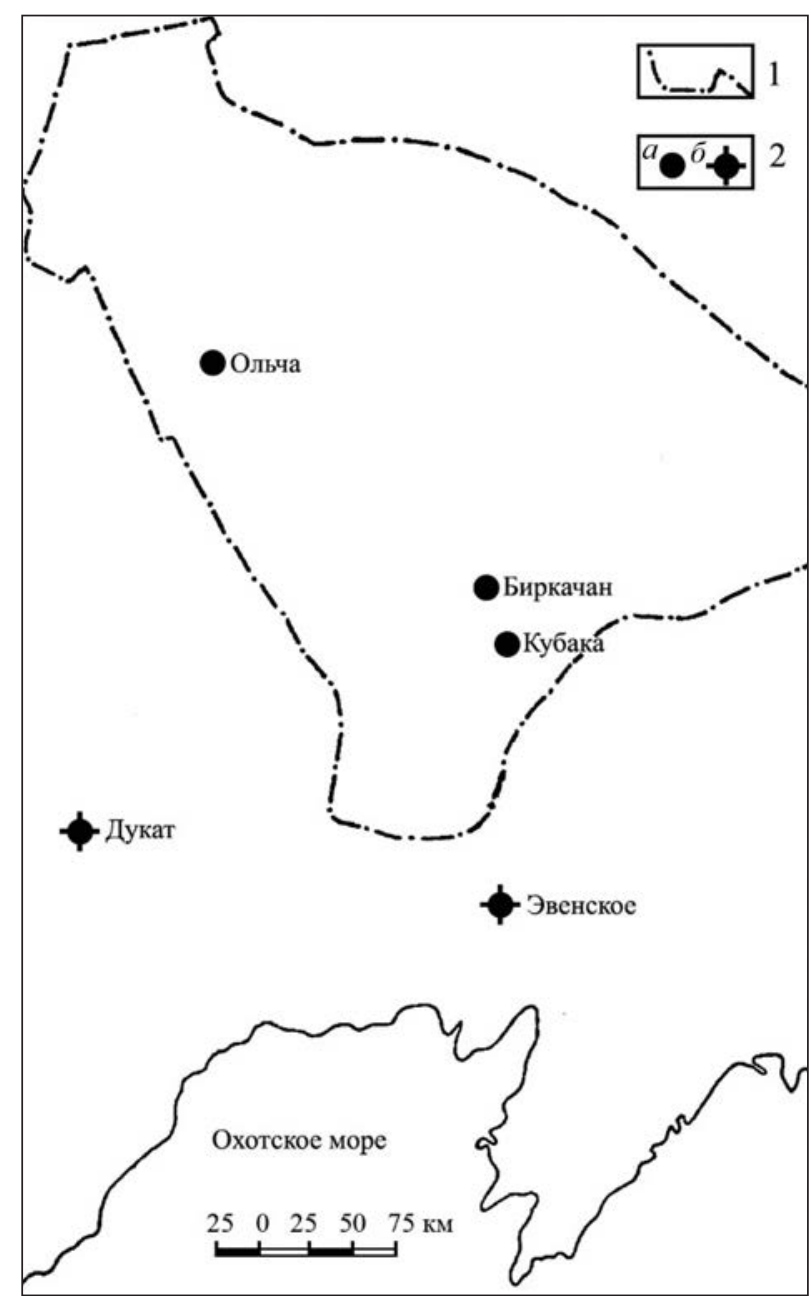

Рuc. 1. Золото-серебряные месторождения Омолонского массива и его окружения: 1 - контур Омолонского массива, 2 - золото-серебряные месторождения палеозойского $(a)$ и мезозойского (б) возраста

Fig. 1. Gold-silver deposits of the Omolon massif and its surroundings: 1 - contour of the Omolon massif, 2 - gold-silver deposits of the Paleozoic (a) and the Mesozoic (б) age 
кластолавами и игнимбритами трахириолитового состава, местами отмечаются тефроиды с потоками пенистых лав риолитов. Околожерловые фации представлены игнимбритами с потоками лав риолитов, сменяемыми к периферии туфами и туфоосадками кислого и среднего состава. Наблюдается отчетливое периклинальное залегание вулканитов под углами 10-20. На периферии палеовулкана развиты, главным образом, удаленные фации вулканитов: разнообразные туфопесчаники, туфоалевролиты, туфы кислого и среднего состава, в том числе пепловые и кремнистые, реже игнимбриты и агломератовые туфы. Вблизи жерла фиксируется серия субвулканических тел трахириолитов, внедренных по концентрическим разломам и имеющих в плане полукольцевую форму. Наклон флюидальности трахириолитов меняется от 60-80 вблизи жерла до $10-30^{\circ}$ на удалении от него. На периферии палеовулкана отмечается серия субвулканических тел, экструзий, силлов и даек переменного состава от преобладающих риодацитов и трахириолитов до трахиандезитов (Степанов, Шишакова, 1994).

Месторождение Кубака расположено на юговосточной периферии Авландинского палеовулкана. Оно является типичным представителем месторождений близповерхностной золотосеребряной формации (Степанов, 1994; Котляр, 2000; Черняев, Черняева, 2001; Савва и др., 2007; Акинин и др., 2020). Об этом свидетельствуют приуроченность месторождения к палеовулканической структуре, контроль оруденения субвулканическими интрузиями риодацитового состава, адуляркварцевый состав убогосульфидных руд с характерными колломорфно-полосчатыми, каркасно-пластинчатыми, кокардовыми и другими текстурами (рис. 2, 3), тонкое низкопробное самородное золото, низкотемпературные калиевые околорудные метасоматиты.

Геологический возраст золото-серебряного оруденения устанавливается достаточно уверенно. Нижняя граница его определяется нахождением рудных тел среди наземных вулканитов и субвулканических интрузий кедонской серии позднего девона. Вулканиты представлены полого залегающими туфами, игнимбритами, туфопесчаниками и туфоалев- ролитами. Особенное значение для локализации рудных тел имеет силл риодацитового состава. Он занимает определенное положение в разрезе вулканитов, располагаясь между подошвой игнимбритов и кровлей туфопесчаников кубакинской свиты кедонской серии. Мощность силла меняется от десятков до 120 м, площадь около 0.9 км$^{2}$. Наклон силла под углами 5-10 совпадает со слоистостью вулканитов. Силл контролирует размещение рудных тел, которые приурочены к его западному, утоненному краю. Рудные тела ориентированы субвертикально (рис. 4). Они пересекают силл и подстилающие туфопесчаники. В пределах силла резко увеличивается мощность рудных тел с одновременным возрастанием в них содержаний золота. В подстилающих туфопесчаниках рудные тела выклиниваются. Поскольку генетическая связь золото-серебряного оруденения с вмещающими оруденение вулканитами достаточно хорошо доказана, то время формирования месторождения Кубака оценивается по возрасту вулканитов кедонской серии как позднедевонское.

Верхняя возрастная граница золото-серебряного оруденения определяется наличием обломков руд (рудокласт) в базальном горизонте терригенных отложений корбинской свиты раннекарбонового возраста (Степанов, Лайпанов, 1991).

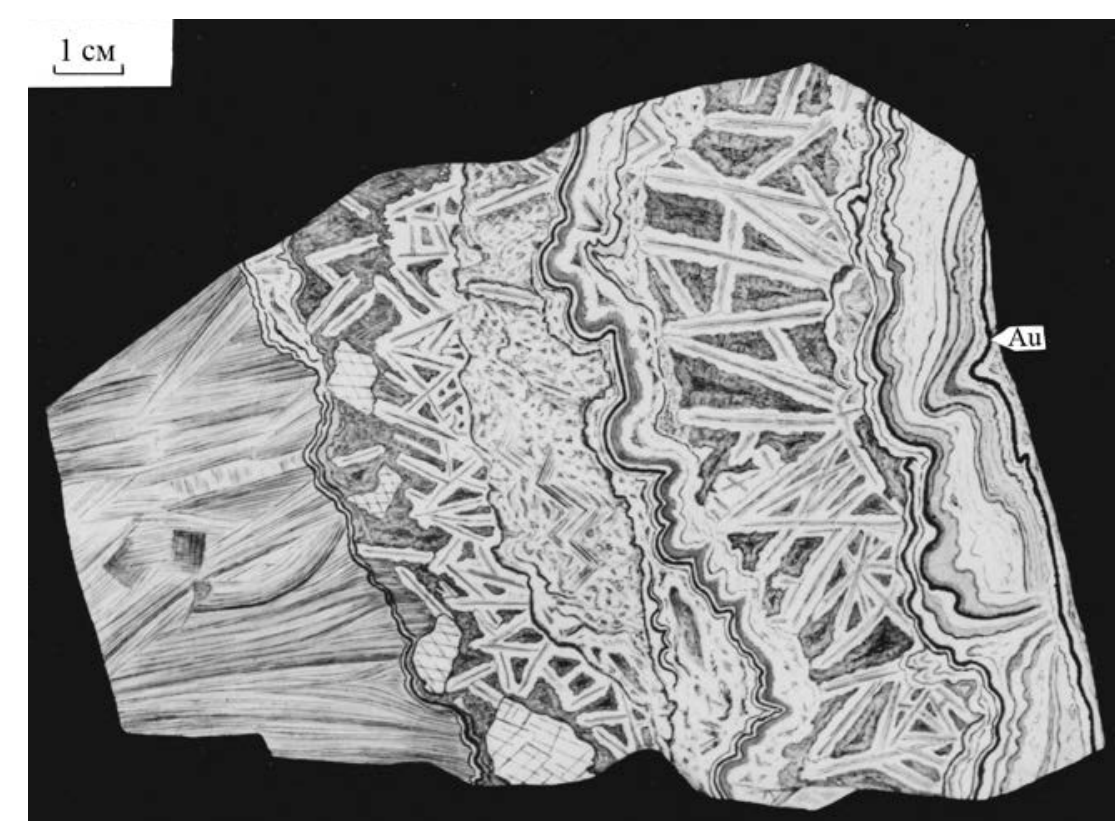

Puc. 2. Сочетание фестончато-полосчатой, каркасно-пластинчатой и тонкопластинчатой текстур в грубополосчатой руде адуляр-кварцевого состава. Полоски черного халцедоновидного кварца наполнены вкрапленностью тонкого золота

Fig. 2. Festoon-banded, framboidal-platy, and sliced textures combined in coarsely banded ore of adular-quartz composition. Bands of black chalcedony quartz are filled with fine gold impregnation 


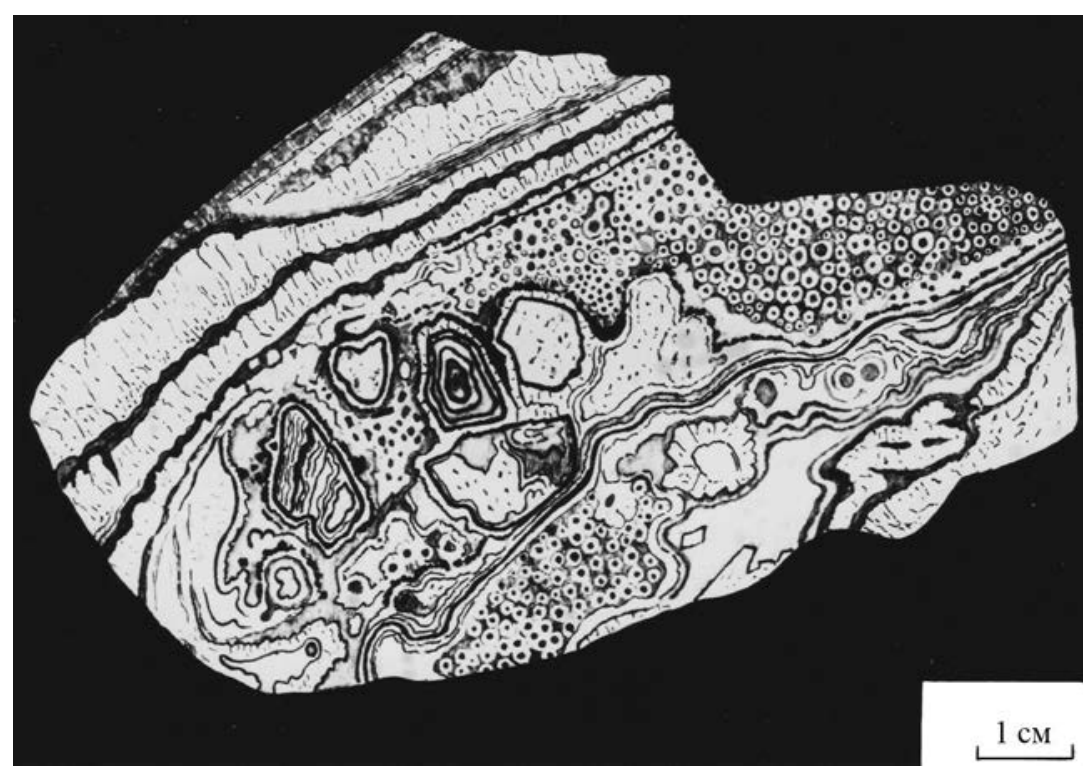

Рuc. 3. Адуляр-кварцевая руда с полосчатой, кокардовой и сферолитовой текстурами. Полоски черного халцедоновидного кварца наполнены тонкими включениями золота

Fig. 3. Adular-quartz ore with banded, cocarde, and spherolitic textures. Bands of black chalcedony quartz are filled with fine inclusions of gold

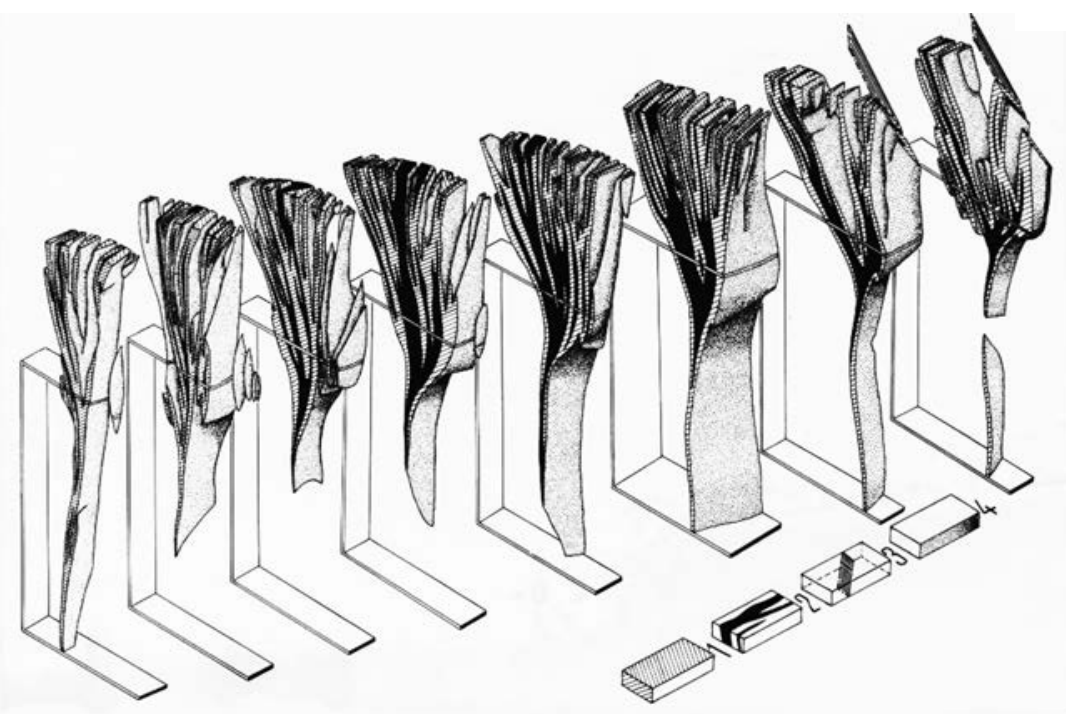

Рис. 4. Раздвинутая объемная модель рудного тела Центральной рудной зоны: 1 - зоны прожилкового окварцевания; 2 - адуляр-кварцевые жилы; 3 - поверхности поперечных разломов; 4 - боковые поверхности жил и прожилковых зон

Fig. 4. Extended volume model of the ore body of the Central ore zone: $1-$ zones of veined quartz formation; 2 - adular-quartz veins; 3 - surfaces of transverse faults; 4 - lateral surfaces of lodes and veined zones

Отложения корбинской свиты, несогласно залегающие на вулканитах кубакинской свиты, отмечаются на юго-западном фланге месторождения. Они представлены углисто-глинистыми сланцами с отпечатками флоры плохой сохранности и алевролитами с прослоями песчаников. В основании свиты повсеместно наблюдается ба- зальный горизонт, сложенный гравелитами, осадочными брекчиями и мелкогалечными конгломератами, чередующимися со слоями песчаников и алевролитов. Отчетливо проявлена градационная слоистость горизонта, выраженная в наличии ритмов мощностью от десятков сантиметров до первых метров. Среди обломочного материала находятся лито- и кристаллокласты. Кристаллокласты представлены обломками плагиоклаза, кварца, биотита, мусковита и пирита. Среди литокласт отмечаются обломки гидротермально измененных вулканитов, кварцевых, реже адуляркварцевых жил, андезидацитов, гранитов, даек лампрофиров и гематитизированных флюидальных риолитов. Особый интерес вызывают обломки золотоносных кварцевых жил. Они представлены в основном ранними генерациями метасоматического кварца, реже кварца с реликтами ритмично-полосчатой и каркасно-пластинчатой текстур. Нейтронно-активационный анализ материала, высверленного из этих обломков в полировках керна, показал содержание золота от 2.2 до 23.9 г/т, серебра от 1.4 до 12.7 $\Gamma /$, т. е. это обломки руды или рудокласты (рис. 5).

При рассмотрении геологического возраста оруденения нельзя игнорировать и пострудные процессы. На месторождении Кубака к пострудным отнесены дайки и силлы долеритов и трахидолеритов омолонского комплекса, возраст которых оценивается как юрский. Дайки располагаются в вулканитах позднедевонского возраста, а силлы отмечаются среди перекрывающих вулканиты терригенных пород корбинской свиты. Дайки в пределах северной части месторождения группируются в пучки из двух-трех даек, а в южной встречаются одиночные дайки. Они ориентированы в северо-восточном направлении вкрест простирания рудных тел, выполняя крутонаклонные нарушения. Центральную рудную зону пере- 


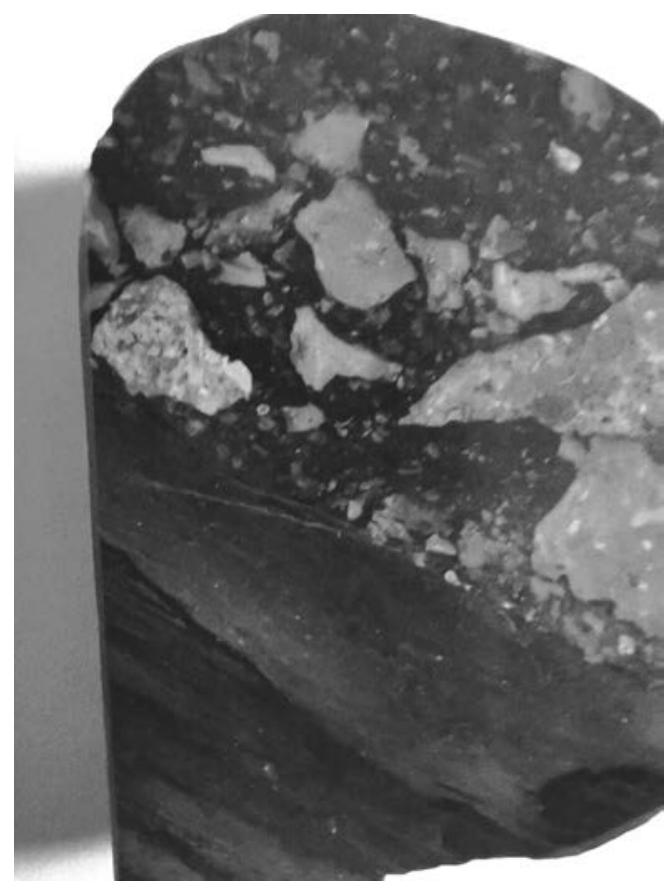

Рuc. 5. Рудокласты в базальном горизонте корбинской свиты (полировка керна скв. С-788)

Fig. 5. Ore clasts in the basal horizon of the Korbinsky suite (core polished section from Borehole S-788)

секает около 10 даек, на глубине их количество увеличивается. Дайки почти под прямым углом секут адуляр-кварцевые жилы, зоны прожилкового окварцевания и гидротермально измененных пород. При этом морфология и внутреннее строение рудных жил на участках их пересечения дайками не меняется. Как правило, по одну и другую сторону секущей дайки наблюдается непосредственное продолжение рудной жилы с присущими ей элементами внутреннего строения. При пересечении дайкой жилы с полосчатой текстурой рисунок полосчатости сохраняется в раздвинутых дайкой участках жил. Сопоставимы и мощности жил по обе стороны дайки, сохраняется также ширина сопровождающих жилы зон окварцевания и гидротермально измененных пород.

Дискуссионным является вопрос о влиянии даек долеритов на золото-серебряное оруденение. Термического воздействия даек на рудные тела обычно не наблюдается. Хотя в одном случае в золотоносных адуляр-кварцевых прожилках были визуально обнаружены слабо выраженные приконтактовые изменения (рис. 6). Рудоносные прожилки имеют зональное строение: в зальбандах они сложены тонкополосчатым адуляркварцевым агрегатом, а в центральной части равномерно-зернистым агрегатом кварца и кальцита с хлоритом. На фото пришлифовки видно, что по мере приближения к дайке в рудоносных прожилках появляется все больше новообразова-

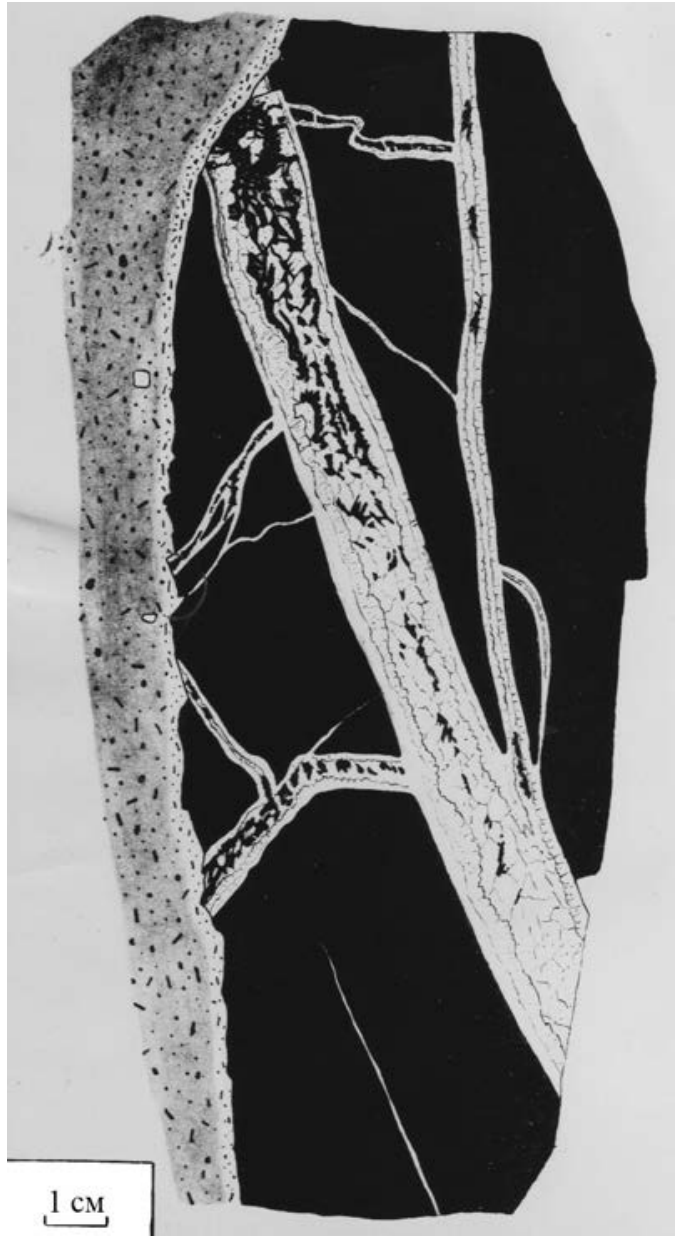

Рис. 6. Контакт долеритов (слева) с адуляркварцевыми прожилками

Fig. 6. Contact of dolerites (left) with adular-quartz veins

ний хлорита. В ассоциации с хлоритом отмечаются анкерит и лейкоксен, а вблизи контакта дайки - мелкие кристаллы арсенопирита. Эти изменения не существенны и не вносят коррективы в содержания полезных компонентов руд, но могли повлиять на изотопное соотношение элементов нерудных минералов - геохронометров.

Для определения влияния дайки на характер золотого оруденения составлен план опробования рудного тела в изоконцентратах (рис. 7). На рис. 7 видно, что в распределении золота в рудном теле не наблюдается какой-либо определенной зависимости от приближения к контактам дайки. Общий рисунок содержаний золота отчетливо сохраняется по обе стороны раздвинутого дайкой рудного тела, хотя график изменений содержаний золота, составленный по отдельным штуфным пробам, может дать ошибочное представление о наличии вблизи дайки обогащенных участков.

Приведенные геологические факты доказывают позднедевонский или раннекаменноугольный возраст золото-серебряного оруденения место- 


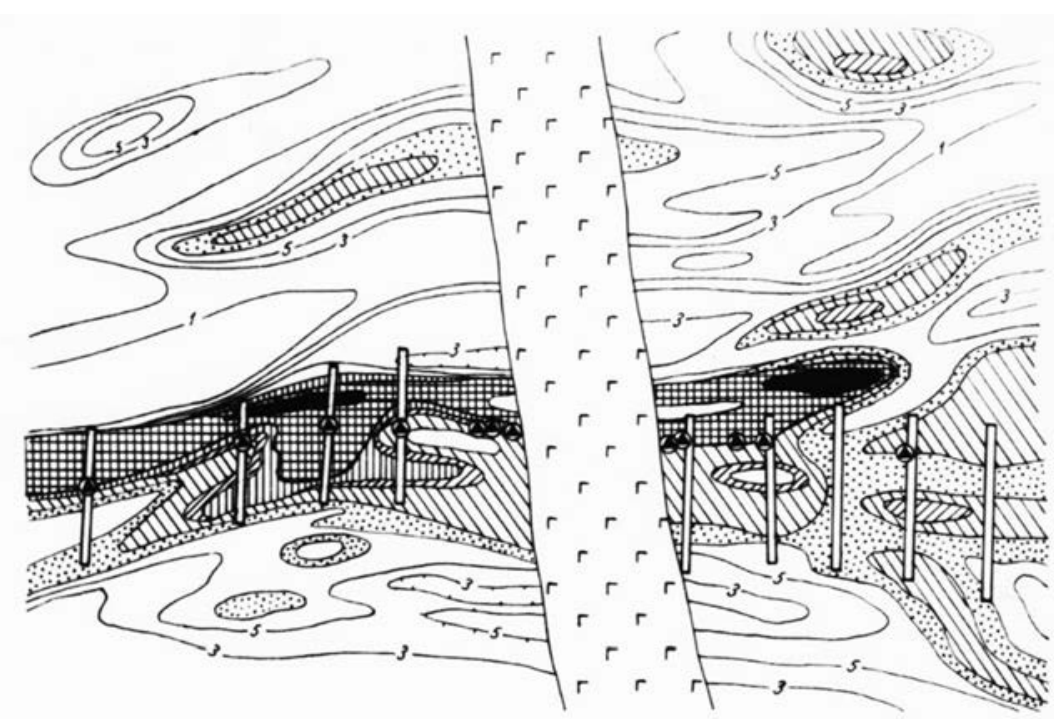

$\mathrm{Au}, \mathrm{r} / \mathrm{T}$

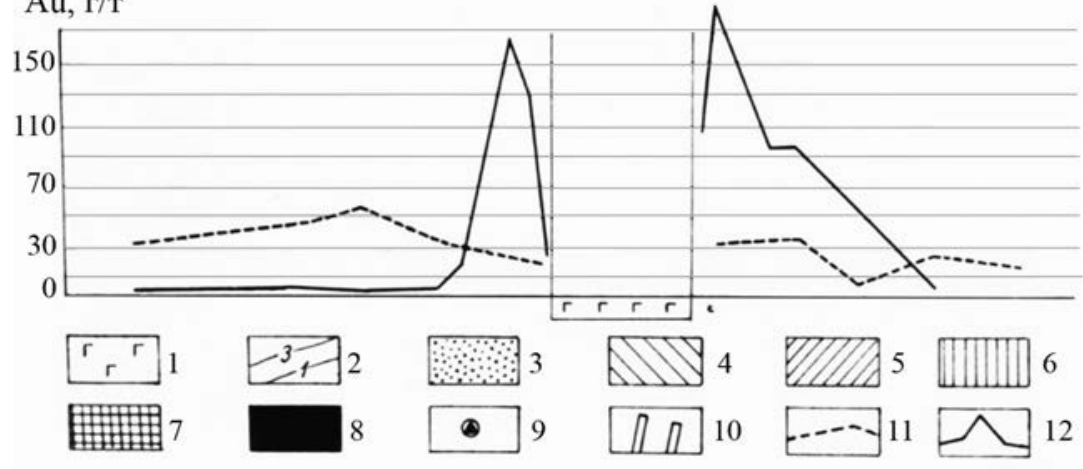

Puc. 7. Распределение золота в рудном теле, пересеченном дайкой долеритов: 1 - долериты; 2 - изоконцентраты золота в г/т; 3-8 - участки с разными содержаниями золота в г/т: 3 - 10-20, 4 - 20-40, 5 - 40-50, 6 - 50-80, 7 - 80-100, 8 - более 100; 9 - места отбора штуфных проб, 10 - линии бороздового опробования; 11,12 - графики содержания золота по данным опробования: 11 - бороздового, 12 - штуфного

Fig. 7. Gold distribution in the ore body crisscrossed by a dolerite dike : 1 - dolerites; 2 - gold isoconcentrates in $\mathrm{g} / \mathrm{t}$; $3-8$ - sites with different gold grades in g/t: 3 - 10-20, 4 - 20-40, 5 - 40-50, 6 - 50-80, 7 - 80-100, 8 - above 100; 9 - grab sampling sites; 10 - channel sampling lines; 11, 12 - gold grade graphs according to the sampling data: 11 - channel sampling, 12 - grab sampling

рождения Кубака. Нижней возрастной границей является возраст вмещающих оруденение вулканитов кедонской серии позднего девона, а верхней - раннекаменноугольный возраст терригенных отложений корбинской свиты, перекрывающих вулканиты и золото-серебряное оруденение, где в базальном горизонте свиты найдены рудокласты.

\section{ИЗОТОПНЫЙ ВОЗРАСТ}

Первые определения изотопного возраста золото-серебряного оруденения Кубаки выполнены калий-аргоновым методом. Они показали $88.1,113.7$ и 312 млн лет, что отвечает позднему мелу, верхам раннего мела и среднему карбону
(И. Н. Котляр, Р. Б. Умитбаев, 1985 г.). По данным В. А. Гуменюка, рубидий-стронциевый анализ адуляра из рудных тел Центральной рудной зоны показал возраст $169 \pm 9$ млн лет по 5 пробам (средняя юра) и более древний по 2 пробам (В. А. Гуменюк, 1988 г.).

Следующими были исследования по радиоизотопному датированию возраста золотосеребряных месторождений Дальнего Востока, в том числе Кубаки, ${ }^{40} \mathrm{Ar} /{ }^{39} \mathrm{Ar}$ методом (Лейер и др., 1997). Даты изотопного возраста адуляров из руд месторождения варьировали от 149 до 121 млн лет $\left(\mathrm{J}_{3}-\right.$ ранний мел).

Затем была произведена серия анализов изотопного во3раста рудосопровождающих минералов (адуляра, гидрослюд и карбонатов) из образцов рудных тел Центральной рудной зоны в лаборатории изотопной геологии ВСЕГЕИ, г. Санкт-Петербург Rb-Sr методом (Степанов и др., 1998). В результате получены четыре изохроны. Две самые древние изохроны $(335 \pm 5$ и $330 \pm 9$ млн лет) близки друг другу и указывают на раннекаменноугольный возраст основной части оруденения. Две другие изохроны указывают на возраст $160 \pm 12$ млн лет (поздняя юра) и $128 \pm 5$ млн лет (ранний мел).

В 1999 г. опубликованы данные по изотопному возрасту месторождения Кубака, определенному K-Ar и $\mathrm{Rb}-\mathrm{Sr}$ методами из образцов руд и метасоматитов Центральной рудной зоны, отобранных А. Н. Рябовым, В. А. Степановым и Е. М. Беловым (Шергина и др., 1999). Возраст гидрослюд околорудных метасоматитов из коллекции А. Н. Рябова определен $\mathrm{Rb}-\mathrm{Sr}$ методом в $335 \pm 5$ млн лет. Близкий возраст дают пробы коллекции В. А. Степанова из руд месторождения - 330 9 млн лет. Но изотопный возраст адуляров из коллекции А. Н. Рябова дает другие результаты. Они оцениваются $\mathrm{Rb}-\mathrm{Sr}$ методом в $128 \pm 5$ млн лет, a K-Ar методом в $125 \pm 6$ млн лет. Кроме того, в трех пробах из коллекции А. Н. Рябова изотоп- 
ный возраст адуляров, определенный $\mathrm{Rb}-\mathrm{Sr}$ методом, составляет $166 \pm 9$ млн лет. Авторы приходят к выводу о существовании значительно разделенных по времени этапов золоторудной минерализации: палеозойского (335 \pm 5 и $330 \pm$ 9 млн лет, визейский век раннего карбона) и двух мезозойских (169 9 , байосский век средней юры и $125 \pm 6$, барремский век раннего мела).

Детальный анализ представлений о возрасте руд месторождения Кубака содержится в работе И. Н. Котляра с соавторами (Котляр и др., 2001). Показано, что возраст руд этого месторождения является раннекарбоновым. Приведен $\mathrm{Rb}-\mathrm{Sr}$ изохронный возраст рудовмещающих оруденение трахириодацитов (344 \pm 4 млн лет) и трахиандезитов $(337 \pm 8$ млн лет) в пределах визейского века раннего карбона.

Коллективом исследователей из ЦНИГРИ в 2002 г. были опубликованы результаты $\mathrm{Rb}-\mathrm{Sr}$ анализа адуляров из руд месторождения Кубака и аналогичного золото-серебряного месторождения Биркачан, также расположенного в вулканитах кедонской серии. Анализы показывают два возрастных интервала формирования этих месторождений: 334-324 (ранний карбон) и 173148 млн лет (средняя - поздняя юра) (Наталенко и др., 2002).

Спустя почти два десятка лет возобновилась дискуссия о возрасте руд месторождения Кубака (Акинин и др., 2020). Приведены новые изотопно-геохронологические данные по Цокольной рудной зоне месторождения. Предыдущие исследователи изучали главным образом Центральную рудную зону. В. В. Акинин с коллегами исследовали изотопный возраст вмещающих золото-серебряное оруденение туфов кубакинской свиты (U-Pb методом по циркону), пострудных даек омолонского комплекса и жильного адуляра $\left({ }^{40} \mathrm{Ar} /{ }^{39} \mathrm{Ar}\right.$ методом). Средневзвешенный ${ }^{206} \mathrm{~Pb} /{ }^{238} \mathrm{U}$ возраст туфов кубакинской свиты составил $369.5 \pm$ 2.4 млн лет (поздний девон). Адуляр из золотоносной жилы показал K-Ar дату остывания около 232 млн лет, а более точное $\mathrm{Ar} / \mathrm{Ar}$ датирование показало возраст плато $299 \pm 3.5$ млн лет (граница между каменноугольным и пермским периодами). В пострудной дайке трахибазальтов ${ }^{40} \mathrm{Ar} /{ }^{39} \mathrm{Ar}$ методом датированы плагиоклаз и основная масса, состоящая из лейст плагиоклаза, девитрифицированного стекла и микролитов магнетита. Для основной массы возраст плато составил $179 \pm 8$ млн лет. Возраст обратной изохроны также соответствует ранней - средней юре. Проба с монофракцией плагиоклаза показала близкие значения возраста обратной изохроны $176 \pm 10$ млн лет.

\section{ОБСУЖДЕНИЕ}

Сравнение результатов определения возраста золото-серебряного месторождения Кубака геологическими и изотопными исследованиями показало следующее. Геологический возраст находится в вилке между позднедевонским возрастом вмещающих золото-серебряное оруденение вулканитов кедонской серии и раннекаменноугольным возрастом перекрывающих вулканиты и оруденение терригенных пород корбинской свиты. Важное значение имеют находки рудокласт в базальном горизонте отложений корбинской свиты. Следовательно, геологические данные однозначно указывают на позднедевонский или раннекаменноугольный возраст формирования месторождения. Геологическими наблюдениями также доказан пострудный характер даек омолонского комплекса. Показано, что дайки не влияют на распределение золотой минерализации в рудных телах, но термальное воздействие даек могло внести коррективы в изотопное соотношение элементов в калий- и рубидийсодержащих минералах в рудах и околорудных метасоматитах.

Проведенные в значительном количестве изотопные анализы позволили в значительной мере уточнить возраст вмещающих оруденение вулканитов, субвулканических интрузий, околорудных метасоматитов, рудных тел и пострудных даек долеритов омолонского комплекса. Изотопные исследования ${ }^{206} \mathrm{~Pb} /{ }^{238} \mathrm{U}$ методом по цирконам определили позднедевонский возраст туфов кубакинской свиты, вмещающих золото-

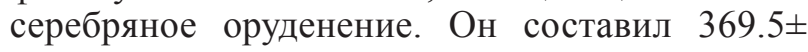
2,4 млн лет, что отвечает позднему девону (Акинин и др., 2020). Изохронный возраст рудоконтролирующих субвулканических тел, определенный $\mathrm{Rb}-\mathrm{Sr}$ методом, значительно моложе и составляет $344 \pm 4$ млн лет для трахириодацитов и $337 \pm 8$ млн лет для трахиандезитов, что отвечает раннему карбону (Котляр и др., 2001). Изотопный возраст околорудных метасоматитов определен $\mathrm{Rb}-\mathrm{Sr}$ методом в $335 \pm 5$ млн лет (Шергина и др., 1999). Он значительно моложе возраста вмещающих оруденение туфов, определенного U-Pb методом в $369 \pm 2.4$ млн лет, и близок к возрасту субвулканических пород, определенному $\mathrm{Rb}-\mathrm{Sr}$ методом в $344 \pm 4$ и $337 \pm$ 8 млн лет (Котляр и др., 2001).

Изотопный возраст руд определяли Rb$\mathrm{Sr}, \mathrm{K}-\mathrm{Ar}$ и ${ }^{40} \mathrm{Ar} /{ }^{39} \mathrm{Ar}$ методами. Наиболее древние определения дает изохронный $\mathrm{Rb}-\mathrm{Sr}$ метод, согласно которому формирование золотосеребряного оруденения происходило в раннем карбоне 330 млн лет назад (Степанов и др., 1998; Шергина и др., 1999). Близкий возраст оруденения в 334-324 млн лет, определенный Rb-Sr ме- 
тодом, приведен в работе (Наталенко и др., 2002). $\mathrm{K}-\mathrm{Ar}$ метод дает 312 млн лет, т. е. средний карбон (И. Н. Котляр, Р. Б. Умитбаев, 1985 г.). Исследование адуляра из золотоносной жилы Цокольной зоны месторождения ${ }^{40} \mathrm{Ar} /{ }^{39} \mathrm{Ar}$ методом выявило возраст оруденения в $299 \pm 3.5$ млн лет (Акинин и др., 2020), что фиксирует границу между каменноугольным и пермским периодами. На еще более молодой изотопный $\mathrm{Ar} / \mathrm{Ar}$ возраст адуляров из руд Центральной рудной зоны месторождения в пределах от 149 до 121 млн лет $\left(\mathrm{J}_{3}\right.$ - ранний мел) указано в работе (Лейер и др., 1997).

По данным U-Pb и $\mathrm{Rb}-\mathrm{Sr}$ датирования выстраивается логически стройная цепочка сменяющих друг друга во временной последовательности этапов формирования Кубакинского месторождения: накопление туфов кубакинской свиты (369 млн лет) - внедрение субвулканических интрузий (344 и 337 млн лет) - образование околорудных метасоматитов ( $335 \pm 5$ млн лет) - формирование золотосеребряного оруденения (334-324 млн лет).

Результаты $\mathrm{Ar} / \mathrm{Ar}$ датирования указывают

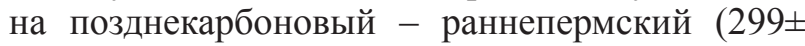
3.5 млн лет) или $\mathrm{J}_{3}-$ раннемеловой (149 до 121 млн лет) возраст золото-серебряного оруденения. Они значительно занижают возраст оруденения, полученный $\mathrm{Rb}-\mathrm{Sr}$ методом, ставя под сомнение раннекарбоновый возраст отложений корбинской свиты, в базальном горизонте которой обнаружены рудокласты.

Время внедрения пострудных даек трахибазальтов омолонского комплекса оценивается ${ }^{40} \mathrm{Ar} /{ }^{39} \mathrm{Ar}$ методом по основной массе пород в $179 \pm 8$ млн лет, а по монофракции плагиоклаза в $176 \pm 10$ млн лет (Акинин и др., 2020), что отвечает ранней - средней юре. Влиянием этих даек на руды месторождения, вероятно, можно объяснить появление относительно молодых $\mathrm{Rb}-\mathrm{Sr}$ дат в $169 \pm 9$ (ранняя - средняя юра) и $160 \pm 12$ млн лет (средняя - поздняя юра) (Степанов и др., 1998; Шергина и др., 1999).

\section{ВЫВОДЫ}

На примере месторождения Кубака показано, что как геологические, так и изотопные исследования внесли свой взаимодополняющий вклад в определение возраста этого месторождения. Геологическими исследованиями установлено, что формирование месторождения Кубака находится в вилке между позднедевонскими датами вмещающих золото-серебряное оруденение вулканитов кедонской серии и раннекаменноугольными значениями дат перекрывающих вулканиты и оруденение терригенных пород корбинской свиты. Кроме того, доказан пострудный характер даек омолонского комплекса, которые существенно не влияют на распределение золотой минерализации в рудных телах.
Изотопными определениями значительно конкретизированы возрастные даты отдельных геологических событий. Выделяются следующие крупные этапы формирования Кубакинского месторождения: накопление рудовмещающих туфов кубакинской свиты (369 млн лет) - внедрение субвулканических интрузий (344 и 337 млн лет) - образование околорудных метасоматитов ( $335 \pm 5$ млн лет) - формирование богатого золото-серебряного оруденения (334-324 млн лет). Неминерализованные пострудные дайки внедрены $179 \pm 8$ или $176 \pm 10$ млн лет назад. Изотопные анализы, указывающие на раннемеловой этап формирования золото-серебряного оруденения, не находят подтверждения в геологическом строении месторождения.

\section{ЛИТЕРАТУРА}

Акинин В. В., Глухов А. Н., Ползуненков Г. О., Альшевский А. В., Алексеев Д. И. Возраст эпитермального золото-серебряного оруденения на месторождении Кубака (Омолонский кратонный террейн, Северо-Восток России): геологические и изотопногеохронологические (U-Pb, $\left.{ }^{39} \mathrm{Ar} /{ }^{40} \mathrm{Ar}\right)$ ограничения // Тихоокеанская геология. 2020. Т. 39, № 1. С. 37-47.

Горячев Н. А., Егоров В. Н., Савва Н. Е., Кузнеиов В. М., Фомина М. И., Рожков П. Ю. Геология и металлогения фанерозойских комплексов юга Омолонского массива. Владивосток : Дальнаука, 2017. 312 с.

Котляр И. Н. Возраст золотых руд месторождения Кубака // Магматизм и метаморфизм Северо-Востока Азии : Материалы IV регионального петрографического совещания. Магадан : СВКНИИ ДВО РАН, 2000. C. 156-159.

Котляр И. Н., Жуланова И. Л., Русакова Т. Б., Гагиева А. М. Изотопные системы магматических и метаморфических комплексов Северо-Востока России. Магадан : СВКНИИ ДВО РАН, 2001. 319 с.

Лейер П. В., Иванов В. В., Раткин В. В., Бундиен $T$. $K$. Эпитермальные золото-серебряные месторождения Северо-Востока России: первые ${ }^{40} \mathrm{Ar} /{ }^{39} \mathrm{Ar}$ определения возраста руд // Доклады РАН. 1997. Т. 356, № 5. C. 665-668.

Наталенко М. В., Стружков С. Ф., Рыжсов О. Б., Вакин М. Е., Ииков Б. И., Гиллес Б., Карчавеи В. П., Устинов В. И., Шергина Ю. П. Геологическое строение и минералогия месторождения Биркачан // Руды и металлы. 2002. № 6. С. 37-52.

Савва Н. Е., Волков А. В., Сидоров А. А. Особенности рудообразования на эпитермальном $\mathrm{Au}-\mathrm{Ag}$ месторождении Кубака (Северо-Восток России) // Доклады AH. 2007. T. 417, № 1. C. 79-83.

Степанов В. А. Золото-серебряное месторождение Кубака // Геология рудных месторождений. 1994. T. 36, № 4. C. 362-369.

Степанов В. А., Лайпанов X. Х. О рудокластах близповерхностного золото-серебряного месторождения Омолонского массива // Доклады АН СССР. 1991. T. 316, № 2. C. 444-447.

Степанов В. А., Моисеенко В. Г. Геология золота, серебра и ртути. Часть 1. Золото-ртутные месторождения. Владивосток : Дальнаука, 1993. 228 с. 
Степанов В. А., Шишакова Л. Н. Кубакинское золото-серебряное месторождение. Владивосток : Дальнаука, 1994. 195 с.

Степанов В. А., Шергина Ю. П., Шкорбатова Г. С., Шишакова Л. Н., Рублев А. Г. Возраст руд Кубакинского месторождения золота (Омолонский массив) // Тихоокеанская геология. 1998. Т. 17, № 5. C. 89-97.

Черняев Е. В., Черняева Е. И. Структура и условия локализации золотого оруденения Кубакинского руд- ного поля // Известия Томск. политехн. ун-та. 2001. Т. 304. Вып. 23. С. 225-243.

Шергина Ю. П., Шкорбатова Г. С., Рублев А. Г., Степанов В. А., Рябов А. Н. Изотопно-геохронологические данные о возрасте золото-серебряного месторождения Кубака (Северо-Восток России) // Доклады АН. 1999. Т. 367, № 2. С. 226-229.

Bainbridge $K$. T., Nier A. O. Relative isotopic abundances of the elements : Preliminary Report Nuclear Ser. Washington, 9. 1950. 59 p.

Поступила в редакиию 20.12.2020 2.

Поступила после доработки 30.12.2020 г.

\title{
ON THE GEOLOGICAL AND ISOTOPIC AGE OF GOLD DEPOSITS (Example of the Kubaka Gold-Silver Deposit, North-East of Russia)
}

\author{
V. A. Stepanov \\ Research Geotechnological Center FEB RAS, Petropavlovsk-Kamchatsky
}

\begin{abstract}
Information on the geological and isotopic age of the Kubaka gold-silver deposit in the Omolon middle massif in the North-East of Russia is presented. It has been established that the Kubaka deposit geological age lies in between the Late Devonian age of the Kedon series volcanites, containing the gold-silver mineralization, and the Early Carboniferous age of the Korbinsky suite terrigenous rocks, overlapping the volcanites and the mineralization. The post-ore nature of the Omolon complex dykes, which produce no significant impact on the distribution of gold mineralization in ore bodies, is shown. According to isotope dating, the following stages of the Kubaka deposit formation are distinguished: the accumulation of the Kubaka suite tuffs (369 Ma); the introduction of subvolcanic intrusions ( 344 and $337 \mathrm{Ma}$ ); the formation of ore metasomatites $(335 \pm 5 \mathrm{Ma})$; the formation of gold-silver mineralization (330 and 334-324 Ma); the introduction of post-ore dikes (179 $\pm 8-176 \pm 10 \mathrm{Ma})$.
\end{abstract}

Keywords: gold-silver deposit, mineralization age, isotopic dating, post-ore dykes, volcanites, metasomatites.

\section{REFERENCES}

Akinin, V. V., Glukhov, A. N., Polzunenkov, G. O., Alshevsky, A. V., Alekseyev, D. I., 2020. Age of Epithermal Gold-Silver Mineralization at the Kubaka Deposit (Omolon Cratonic Terrane in the North-East of Russia): Geological and Isotope-Geochronological (U-Pb, ${ }^{39} \mathrm{Ar} /{ }^{40} \mathrm{Ar}$ ) Limitations, Pacific Geology. 39 (1), 37-47 [In Russian].

Bainbridge, K. T., Nier, A. O., 1950. Relative Isotopic Abundances of the Elements, Preliminary Report Nuclear Ser. Washington, 9.

Chernyaev, Ye. V., Chernyaeva, Ye. I., 2001. Structure and Localization Conditions of the Kubaka Ore Field Gold Mineralization, Bulletin of the Tomsk. Polytechnic University. Iss. 23, 304, 225-243 [In Russian].

Goryachev, N. A., Yegorov, V. N., Savva, N. Ye., Kuznetsov, V. M., Fomina, M. I., Rozhkov, P. Yu., 2017. Geology and Metallogeny of Phanerozoic Complexes in the South of the Omolon Massif. Vladivostok, Dalnauka [In Russian].

Kotlyar, I. N., 2000. Age of the Kubaka Deposit Gold Ores, Magmatism and Metamorphism of Northeast Asia.
Materials of the IV Regional Petrographic Meeting. Magadan, NEISRI FEB RAS. 156-159 [In Russian]. Kotlyar, I. N., Zhulanova, I. L., Rusakova, T. B., Gagieva, A. M., 2001. Isotope Systems of Magmatic and Metamorphic Complexes in the North-East of Russia. Magadan, NEISRI FEB RAS [In Russian].

Leyer, P. V., Ivanov, V. V., Ratkin, V. V., Bundzen, T. K., 1997. Epithermal Gold-Silver Deposits of the NorthEast of Russia: First ${ }^{40} \mathrm{Ar} /{ }^{39} \mathrm{Ar}$ Ore Age Determinations, Doklady Akademiyi Nauk. 356 (5). 665-668 [In Russian].

Natalenko, M. V., Struzhkov, S. F., Ryzhov, O. B., Vakin, M. E., Ishkov, B. I., Gilles, B., Karchavets, V. P., Ustinov, V. I., Shergina, Yu. P., 2002. Geological Structure and Mineralogy of the Birkachan Deposit, Ores and Metals. 6, 37-52 [In Russian].

Savva, N. E., Volkov, A. V., Sidorov, A. A., 2007. Peculiarities of Ore Formation at the Kubaka Epithermal Au-Ag Deposit (North-East of Russia), Doklady Akademiyi Nauk. 417 (1). 79-83 [In Russian]. 
Shergina, Yu. P., Shkorbatova, G. S., Rublyov, A. G., Stepanov, V. A., Ryabov, A. N., 1999. Isotope-Geochronological Data on the Age of the Kubaka Gold-Silver Deposit (North-East of Russia), Doklady Akademiyi Nauk. 367 (2), 226-229 [In Russian].

Stepanov, V. A., 1994. Kubaka Gold-Silver Deposit, Geology of Ore Deposits. 36 (4), 362-369 [In Russian].

Stepanov, V. A., Laypanov, Kh. Kh., 1991. On Ore Clasts of the Near-Surface Gold-Silver Deposit of the
Omolon Massif, Doklady Academiyi Nauk SSSR. 316 (2), 444-447 [In Russian].

Stepanov, V. A., Moiseenko, V. G., 1993. Geology of Gold, Silver, and Mercury. Part 1. Gold-Mercury Deposits. Vladivostok, Dalnauka [In Russian].

Stepanov, V. A., Shergina, Yu. P., Shkorbatova, G. S., Shishakova, L. N., Rublyov, A. G., 1998. Age of Ores at the Kubaka Gold Deposit (Omolon massif), Russian Journal of Pacific Geology. 17 (5), 89-97 [In Russian].

Stepanov, V.A., Shishakova, L. N., 1994. Kubaka GoldSilver Deposit. Vladivostok, Dalnauka [In Russian]. 